\title{
Student's Perception Towards Incorporation Hello English Application in Vocabulary Learning
}

\section{Alsuna: Journal of Arabic and English Language}

\section{Haris Nutriyanto \\ Universitas Singaperbangsa Karawang \\ Q harisnurtriyanto@gmail.com}

\section{Keywords:}

Perception

Hello English Application

Vocabulary

Article Information:

Submitted: 06 June, 2020

Accepted: 15 November, 2020

Approved: 28 November, 2020

\section{Abstract}

Purpose - The purpose of the article to know how does the learning process while incorporating Hello English application in vocabulary learning and to know how are student's perception towards incorporating Hello English in English vocabulary learning.

Design/methodology/approach - Research design is used by the writer is qualitative research with narrative design. The research takes from 8th-grade students of SMPN 2 Serang Baru, Bekasi. In the data collection technique, the researcher uses an interview as a way of collecting data. In data analysis, there is four-step, that is data collection, data reduction, data presentation, verification and conclusion.

Findings - In the result, the writer found that students' perception towards incorporating of Hello English in vocabulary learning has positive perception for students as seen from their responses that the Hello English application is a very good application and use in English learning, especially in learning English vocabulary.

Originality/value - Teachers must be creative to create or collaborate with application designs to make language learning applications. Because the problems and learning needs in every school are known only to the teachers who teach.

Paper type - Research paper

\section{Introduction}

Vocabulary is one of the skills in English that must be mastered for every grade. It is as a support for English language component skills such as: Listening, Writing, Reading, Speaking. Vocabulary is needed for students to see how they are used (Harmer 2007). Therefore, through vocabulary, student can communicate and express their feelings, idea, and emotion each others.

Lack of vocabulary is a factor that students difficult to learn English. It can caused by low interest of students or low motivation of students to learn English. Unknowing 
words of students can cause anxiety for students to learn English. Limitation of vocabulary can be impede in communication (Alqahtani 2015). Therefore, it can be teacher's task for disappear anxiety for students to learn English and get increase interest and motivation for students. Teacher can use games, pictures, information and communication technology (ICT) media, or other strategy and material for increase interest and motivation students in acquiring English vocabulary.

In this era, ICT in the world of education has been widely used. This is affects in a material of learning, especially in learning English. As the saying of Liana (2019) that information and communication technology propagates in all aspects of life to the field of education and training are also affected. The impact of ICT, especially in education can be felt at this time. Projectors, laptops, speakers, and mobile learning are some ICT tools that can be used in learning, especially in English learning. By using ICT media, learning activities can be helped especially in learning English.

Perception is a process in acquiring information through sensory receptors and changed into what of think, smell, taste, touch, see, and hear (Ibrohim, Septianti, and Sadikin 2019, 147).

Hello English is a smartphone application designed specifically for learning English (Vesselinov and Grego 2017). Hello English is a specific English language learning for a mobile application that offers comprehensive English language skills through games and interesting scene (Hidayati and Diana 2019, 197). The features of this application are explanation and description of the lesson, lesson quiz, games one vs one that related to English lesson, and the user gets the coins from explanation lesson, lesson quiz, and games. This coins has function for unlock other lessons and as an achievement for the users.

Vocabulary is one of part supporting English skills in which collection of words that understood by someone and used to communicate for each other (Sudrajat and Herlina 2015). Vocabulary is the basis for learning a language. Vocabulary is an important component in learning English because vocabulary is a supporting skill in learning English in addition to grammar and pronunciation. Learning vocabulary is very important in obtaining language, especially in English. There are 2 kinds of vocabulary (Maskor and Baharudin 2016, 263-264):

Receptive Vocabulary Knowledge is the words are known and understood of the meaning of words by learners while the learners are reading or listening to the text. The words in receptive vocabulary are used in context, but which they cannot produce. 
Productive Vocabulary Knowledge is the learners can pronounce and understand the meaning of words. Productive vocabulary can be used in speaking and writing constructively.

In communication purposes, vocabulary mastery is more important than grammar Page | 199 (Gower, Philips, and Walters 1995). Vocabulary is easy to learn, but is often ignored. Vocabulary has important role for be mastered in the four language skills and vocabulary mastery as one of the needed components for acquiring language, especially in English language (Alqahtani 2015). Therefore, learning vocabulary is very important to master because vocabulary is the beginning to facilitate understanding, applying language in communication, especially in learning English.

\section{State of The Art and Distinguish}

In the previous research, clarify that Hello English is a mobile application that can be enriching English vocabulary and as an educator game application in Android for young learners (Puspitaloka, Hasanah, and Rahmawati 2017). In the research title University Students' Perception towards the Use of Duolingo Application in Learning English clarify that the research is for investigated perception of students in using Duolingo application in learning English and in the observation has found that more students use smartphones and laptops in their daily lives; they use smartphones to send messages, call, play games, and check social media; for students, playing games is fun and they can spend time several hours for playing games (Astarilla 2018). Then, in the title Student's Motivation to Learn English using Mobile Application: The Case of Duolingo and Hello English giving differences between Duolingo and Hello English. Duolingo is more focused on enriching vocabulary, for Hello English is more comprehensive English language learning skills through games and interesting scenes (Hidayati and Diana 2019). Then the researchers also found similarities in research related to vocabulary learning through the Total Physical Response method (Fadilah 2011), and the Modified Snakes and Ladders Game (Setiawan and Zuana 2018).

The four research above have similarities that are using applications based on mobile learning and one research above is about strategy for teaching without application based on mobile learning. The first research used the Hello English application to enrich English vocabulary for young learners and use a quantitative method with a quasiexperimental design type. The second research investigated student motivation in using two mobile learning-based applications, namely Duolingo and Hello English with mixed methods. 
The third research investigated students' perceptions of using Duolingo in learning English with a mixed method. Based on previous research, this topic is essential to discuss perception from students about incorporating Hello English in vocabulary learning as an incorporating application based on mobile learning in English vocabulary learning for students by used qualitative design.

This research focused on incorporate Hello English for the student in vocabulary learning. Students must be able to use Hello English in vocabulary learning and students give perception related incorporate of Hello English in vocabulary learning. This article purpose to find out how does the learning process while incorporating of Hello English in vocabulary learning and to find out how are perception from students towards incorporating of Hello English in vocabulary learning.

\section{Methodology}

The location are used as the research field is in SMPN 2 Serang Baru. The duration for researching and collecting the data is about 4 weeks. First week, students give instruction from the writer how to register Hello English and use Hello English to learn vocabulary. Second week and third week, students continue to learn vocabulary through the feature of Hello English . Fourth week, students learn vocabulary through the feature of Hello English and students give their perceptions at the last of learning activity. The respondent target is for 8th grade level. From all classes at the 8th grade level, the writer chooses one class from the 8th grade. This research used 8th grade as a respondent in which they comprehended in long distance online class and they are not preparing for national exam. The respondent must have smartphone for using Hello English.

The research approach that the writer used is a qualitative approach. The type of research design is narrative research. Narrative research is a research design in which researcher collecting data based on life story of individuals or ask to individuals to provide experience about the research subject (Creswell 2014). In data collection technique, the writer use interview for collecting perception students in using Hello English in vocabulary learning. In analyzing data, there are four stage in analysis of data:

1. Data collection is the process of collecting data from research activities carried out through observation and interview activities. Data obtained from research activities are collected as information that will be processed by researchers. 
2. Data reduction is data obtained from research activities selected, classified, directed and discarded unnecessary based on observations and interviews. At this stage, the data obtained needs to be simplified and focused on important matters related to the purpose of this study.

3. Data display is data that has been reduced presented either in the form of descriptions, graphs, or tables. At this stage, researchers describe in detail every data that has been obtained through the previous stage process.

4. Verification and conclusion is the final stages in the analysis of this research. In this stage, the formulation of the problem can be answered from the conclusions and verified that the conclusions obtained are correct and answered for the formulation of this research.

\section{Findings and Discussion}

In the learning process on the use of the Hello English application in learning English vocabulary, learning is carried out through three stages in each meeting.

\section{$1^{\text {st }}$ Meeting}

In the activity at this first meeting, the teacher asks students to use the Hello English application. The teacher provides guidance to students regarding how to register and use the Hello English application.

After students have finished registering, students are asked to open the dictionary menu on the Hello English application. The teacher gives commands to memorize at least 20 vocabulary words. Students send memorization results with voice chat. The teacher evaluates how they pronounce it and the meaning of the word correctly.

Before closing, the teacher gives instructions to students to read stories in the exercise menu, the books feature. The teacher explains that they can find out the meaning of each word in the story text by touching one of the words.

\section{$2^{\text {nd }}$ Meeting}

In the second meeting, the teacher explains next material that is learning vocabulary through the news feature. The teacher asks students to open the Hello English application and enter the training menu, the news feature. In this news feature, students are asked to read one of the news and answer questions related to the news. The questions provided are available under the news text in the Hello English application. The teacher explains that 
students can find words they do not understand by touching one of the words in the news text. Students must show the results of answering questions from the news text to the teacher in the form of screenshots.

Before closing learning, the teacher asks students to try the word of the day feature. In this feature, students are asked to read the news text without being able to translate each word and only answer one question related to the topic of the news text. The questions in the news text feature are related to the similarity of a word or phrase marked in the news text.

\section{$3^{\text {rd }}$ Meeting}

In the third meeting, the teacher explains the next learning, that is learning vocabulary through features articles. In the articles feature, the teacher provides a topic that is in the articles feature. The topic chosen is about 15 tree names in English. Students are asked to search for topics related to 15 tree names in English in the feature article. If you have found the topic, the teacher asks students to read it with good and correct pronunciation.

Before closing the lesson, the teacher asks students to read and memorize one of the topics they are free to choose from the tip of the day feature as their next assignment. The teacher will judge based on their pronunciation.

\section{$4^{\text {th }}$ Meeting}

In the fourth meeting, the teacher explains the next learning, that is learning vocabulary through games in the Hello English application. In the Hello English application, there are four types of games related to sharpening student vocabulary, namely spellathon challenge, vocab games, spelling bee, and tea. Before using games in the Hello English application, students first read the Hello English application usage guide to find out where the features for playing games are. The first feature used by students is the Spellathon Challenge. In the spellathon challenge, students are asked to practice answering vocabulary-related questions quickly against other users from certain regions. The second feature is using the vocab games feature. In the vocab games feature, students must learn the meaning of the vocabulary given in the vocab games feature before starting the test. The third feature is spelling bee. In this feature, students must answer vocabulary-related questions quickly. The last feature is the tea feature. In this feature, students also have to answer vocabulary related questions before the tea water runs out. For each feature they use, students must send a screenshot of the results and the coins they get. 
Before ending the lesson, the teacher asks to several students to fill in questions related to incorporating of Hello English in English vocabulary learning.

Based on the learning process from $1^{\text {st }}$ meeting until $4^{\text {th }}$ meeting, students can use this application easily since the teacher gives the guides how to use it. Students can understand the new vocabulary that acquired through Hello English, so that students' vocabulary knowledge increased.

\section{Student's Perception on Incorporating of Hello English in Vocabulary Learning}

The data of student's perception was collected through interviews with 5 students. In the interview, the writer asked several questions related to their perceptions regarding the incorporating of the Hello English application in vocabulary learning. Students give different opinions about their perception on incorporating of the Hello English application in learning English vocabulary. The findings from the interview can be seen in the extract below.

\section{Extract 1: Student A}

"I am quite helped because I can understand gradually the meaning of
its meaning."
"The application is quite interesting there taught how to say the correct
English words."
"It so difficult and different in how to pronounce, but that helps us to
understand the correct pronunciation of words.

Based on Extract 1 above, the Hello English application can help in understanding vocabulary little by little. An attractive display and taught how to pronounce an English word/phrase properly and correctly. The Hello English application can enrich vocabulary they do not know yet. He has difficult in pronounce, but he can be learn more how to pronounce the words.

\section{Extract 2: Student B}

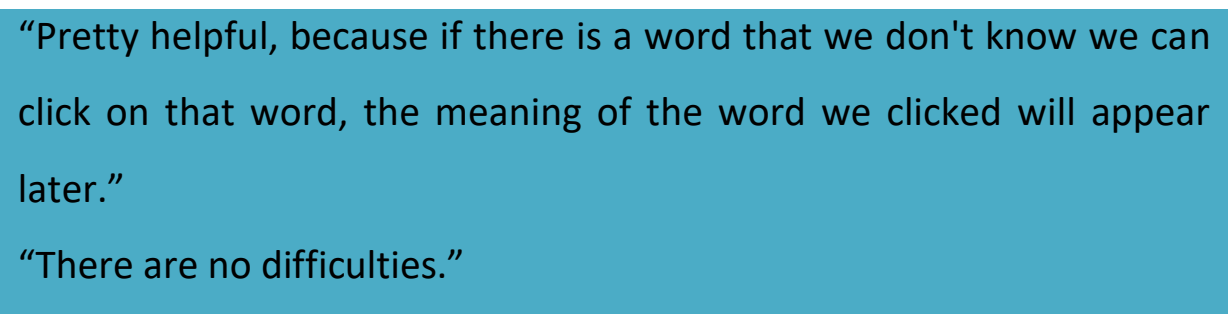

Based on Extract 2 above, Hello English application helps him to learn vocabulary. He said that he could find out the words he did not know by touching them. There are no difficulty for him in using the Hello English application in learning English vocabulary. 


\section{Extract 3: Student C}

Page $\mid 204$

"Learn more about vocabulary in English."
"Yes, the Hello English application is very helpful for me in learning
vocabulary in English because I better understand the vocabulary of
speaking and answering other people's questions correctly using
English."

Based on Extract 3, he argues that learning vocabulary through Hello English can find out more English vocabulary. He can understand how to pronounce good vocabulary and be able to apply it.

\section{Extract 4: Student D}

"It's more exciting than having to use books."

"There are no difficulties and never use it."

Based on Extract 4, he believes that Hello English application is more fun than use books. There is no difficulty in using the Hello English application and even he has never used the Hello English application before.

\section{Extract 5: Student E}

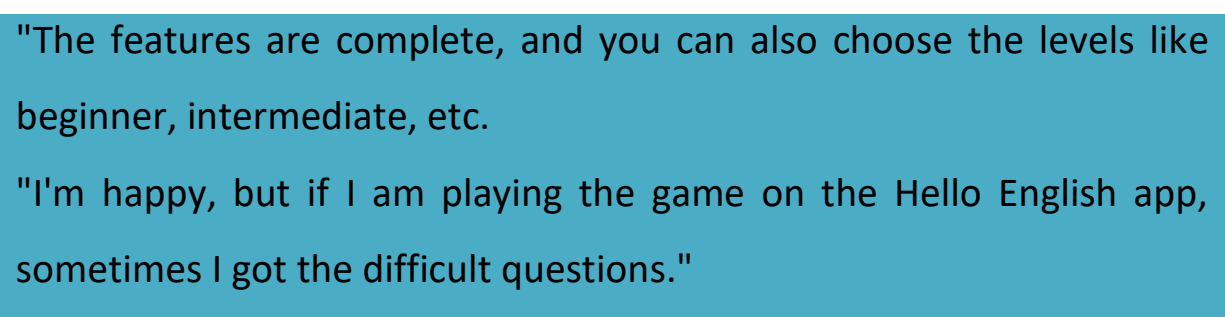

Based on Extract 5, he believes that he likes learning to use the Hello English app even though he always gets questions that are difficult to answer when starting the game at the start. Moreover, the level can be adjusted before using the application.

\section{Extract 6: Student A}

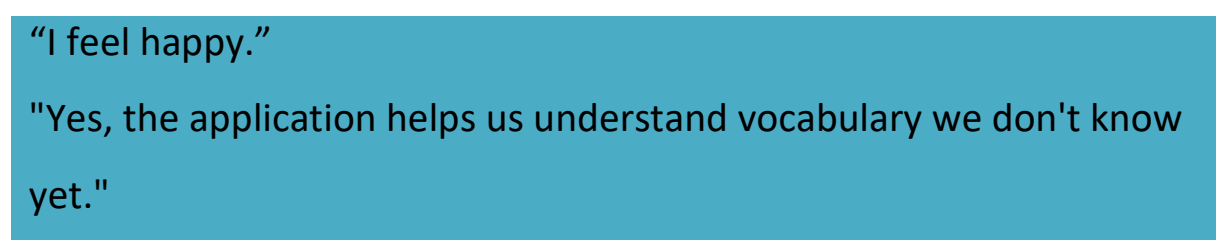

Based on Extract 1 above, he was happy when using Hello English in vocabulary learning. The Hello English application can enrich vocabulary they do not know yet.

\section{Extract 7: Student B}




$$
\begin{aligned}
& \text { "Very practical and easy to use. " } \\
& \text { "Pretty sophisticated and very interesting." } \\
& \text { "Happy because there I can play spellathon challenge." }
\end{aligned}
$$

Based on Extract 2, the Hello English application is very practical and easy to use for her. It has sophisticated features and very attractive appearance. She was very happy to learn vocabulary through the Hello English application, especially she likes the game spellathon challenge.

\section{Extract 8: Student C}

"It was exciting and makes the spirit of learning progress."

"It was happy learn vocabulary with the Hello English app."

Based on Extract 3, she argues that learning vocabulary through Hello English was happy and makes herself motivated to continue learning. Learn vocabulary through Hello English makes her want to learn English more.

\section{Extract 9: Student D}

$$
\begin{aligned}
& \text { "It was very helpful for beginners who want to learn English. the } \\
& \text { application features that make it easy for us as beginners to learn } \\
& \text { English vocabulary that we just heard, } 2 \text { if only the application does } \\
& \text { not have to pay, it will be more fun for as new beginners. " }
\end{aligned}
$$

Based on Extract 4, he believes that Hello English application is very helpful especially for beginners. The feature is so easy for beginners in learn vocabulary and it was even more fun if all the features in the application are until no one pays at all.

\section{Extract 10: Student E}

$$
\begin{aligned}
& \text { "The vocabulary is complete and can be accessed by all people } \\
& \text { without having to pay." } \\
& \text { "Yes, because of this application there are } 10,000 \text { vocabulary words in } \\
& \text { the dictionary." }
\end{aligned}
$$

Based on Extract 5, he believes that Hello English has complete in vocabulary. All people can use Hello English without pay. This application can help him in learning English vocabulary because there are 10,000 words in the dictionary.

From their perception above, the writer knows that students were excited when using Hello English in vocabulary learning. Hello English application can help them to learn 
vocabulary easily and very helpful for beginners. They tells that used Hello English in vocabulary learning is more fun and be motivated for them to learn English vocabulary.

This section is an interpretation of the interviews that have been carried out. Page | 206 Interviews were conducted with several students. This section is divided into 2 parts, that is the learning process on incorporating of Hello English application, student's perception of learn vocabulary by using the Hello English application.

\section{The learning process on using the Hello English application in vocabulary learning}

Based on interviews with them, they have previously learned vocabulary in grade 7 , even up to grade 8 . This shows that they already have experience in learning vocabulary before. They said that before the teacher only used the projector and gave an explanation of each of these words. The student's statement shows that the use of ICT in learning has been very influential. Education is indeed inseparable from the use of ICT which has a positive impact on being able to adapt to innovation and the global era (Liana 2018). ICT media ranging from laptops, projectors, smartphones can be used in education. Learners must use technology as a significant part of their learning process (Ahmadi 2018, 117).

In the process of learning vocabulary using the Hello English application, students are asked to use various features. These features must be related to vocabulary learning. Some features used are dictionaries, books, news, word of the day, articles, tips of the day, spellathon challenge, vocab games, spelling bee, and tea. Learning vocabulary using the Hello English application builds student independence in learning English and fulfills the responsibilities of carrying out the tasks and commands of his teacher. The teacher's duty is to give instructions to students and monitor student activities in learning vocabulary using the Hello English application.

According to Maskor and Baharudin (2016, 263-264), English vocabulary is divided into 2 that is receptive vocabulary knowledge and productive vocabulary knowledge. Receptive vocabulary is words that are known and understood by students when students read or listen to texts, while productive vocabulary is students able to pronounce and understand the meaning of the vocabulary. In learning vocabulary through the Hello English application, students not only can understand the vocabulary, but are able to pronounce it properly and correctly. In some features, students can listen to the pronunciation of a word correctly. In their assessment, students must be able to pronounce the vocabulary they get correctly through voice chat. For them, vocabulary pronunciation is difficult to implement but they 
come to know how to pronounce the correct vocabulary through the Hello English application and become a learning for them to learn better. Through the Hello English application, they become motivated in learning English because it is easy to use and easy to understand.

\section{Student's perception towards incorporating of Hello English in vocabulary learning}

Hello English is one part of ICT media that can provide positive things in English vocabulary learning. This can be seen from the results of the interviews conducted. For student A, the Hello English application helps him to understand the meaning of each English vocabulary gradually. Student B believes that the Hello English application is very sophisticated and easy to understand. Student $C$ has an opinion for her that he can find out more English vocabulary. Student $D$ also has an opinion for himself that it is more fun learning English vocabulary using the Hello English application than learning through books. Student $\mathrm{E}$ also believes that the Hello English application is a good application, has a complete vocabulary and can be accessed by everyone without having to pay. Although they have their own perceptions about learning vocabulary using the Hello English application, the writer knows that learning vocabulary using the Hello English application has positive responses, especially for themselves in English vocabulary learning.

In their feelings when using the Hello English application, they have different perceptions. For student $A$ after using the Hello English application, he feels proud to have used the Hello English application because he feels he can learn English better. Student B said that for her learning vocabulary using the Hello English application was fun especially she liked the spellathon challenge feature. Student $C$ says that she is happy after learning vocabulary using the Hello English application. Student D said that he was very happy to learn English vocabulary using the Hello English application. Student E said that he also enjoyed learning English vocabulary using the Hello English application even though when he joined the game he sometimes got questions that were difficult for him to answer. From their perception of their feelings after learning English vocabulary, the writer knows that the Hello English application is a fun application in learning English vocabulary.

For about Hello English can help students in learn vocabulary, student A believes that Hello English is indeed to help in learning English, especially in English vocabulary learning that they did not even know yet. Student B believes that Hello English can help in learning English vocabulary because there are features that can translate each word from a news text or story. Based on the opinion student $B$, this feature helps users to understand the meaning of each 
word of a text when the user is reading a story or news in English in the application. To display the translation of each word of a text, users only need to press on the word you want to know.

Then, from student $\mathrm{C}$ tells that Hello English is an application that helps in learning Page | 208 English vocabulary because she can understand how to pronounce each word correctly and can answer questions using English. Student D believes that Hello English is very helpful in learning English vocabulary, especially for beginners. Student E also believes that Hello English makes it easy for students to learn English vocabulary. There are 10,000 vocabularies in the Hello English dictionary feature so this application is considered helpful in learning English vocabulary.

For their difficulty, In terms of their difficulties when using the Hello English application in English vocabulary learning, they argue that there is no difficulty for them when using the Hello English application in English vocabulary learning. However, student A said that he had a bit difficulty for him, that is the way he spoke that was difficult and felt different. According to Maskor and Baharudin (2015) English vocabulary is divided into 2 that is receptive vocabulary knowledge and productive vocabulary knowledge. The difficulty of student $A$ is found in productive vocabulary knowledge. From the difficulty of student, A when using the Hello English application, understanding the meaning of a word is easier than pronouncing it.

\section{Conclusion}

The learning process has been carried out smoothly based on instructions from the teacher. The process of learning vocabulary in using the Hello English application can make students motivated to continue learning English. In their use, they have not difficult in use the application, but in pronunciation of the word is still considered difficult for them. Based on the results of the interview, the authors suggest that students' perceptions of the incorporation of the Hello English application in vocabulary learning have positive perceptions.

\section{Implications of Findings}

The implication of the result is Hello English application can be considered as a technology media that makes it easier for students to learn English, especially in learning English vocabulary. Students were happy while used Hello English in vocabulary learning and easier to understand of vocabulary using Hello English. Besides that, teachers should explore 
more about the use of other technological media that are able to provide convenience in teaching and learning English, especially English vocabulary. Students must be more diligent in learning English, not only in school but students must learn outside of school. Therefore, students can use the Hello English application as a media for learning English independently.

\section{Bibliography}

Ahmadi, Dr. Mohammad Reza, and Guilan University, Guilan, Iran. 2018. 'The Use of Technology in English Language Learning: A Literature Review'. International Journal of Research in English Education 3 (2): 115-25. https://doi.org/10.29252/ijree.3.2.115. Alqahtani, Mofareh. 2015. 'The Importance of Vocabulary in Language Learning and How to Be Taught'. International Journal of Teaching and Education III (3): 21-34. https://doi.org/10.20472/TE.2015.3.3.002.

Astarilla, Liya. 2018. 'University Students' Perception towards the Use of Duolingo Application in Learning English'. In Conference Proceedings Vol 3 (2018): CELSciTech towards Downstream and Commercialization of Research, 3:9. http://ejurnal.umri.ac.id/index.php/PCST/article/view/985.

Creswell, John W. 2014. Research Design: Qualitative, Quantitative, and Mixed Methods Approaches. 4th Edition. California: SAGE Publications.

Fadilah, Misra. 2011. 'The Effectiveness of Teaching Vocabulary Though Total Physical Responce Method; an Experimental Study at the Seventh Grade Students of MTs Khazanah Kebajikan Pondok Cabe Ilir'. UIN Syarif Hidayatullah Jakarta. http://repository.uinjkt.ac.id/dspace/handle/123456789/1592.

Gower, Roger, Diane Philips, and Steve Walters. 1995. Teaching Practice: A Handbook For Teachers In Training. Oxford: Macmillan.

Harmer, Jeremy. 2007. The Practice of English Language Teaching. 4th Edition. Cambridge (UK): Pearson Longman. 
Hidayati, Tuti, and Sari Diana. 2019. 'STUDENTS' MOTIVATION TO LEARN ENGLISH USING MOBILE APPLICATIONS: THE CASE OF DUOLINGO AND HELLO ENGLISH'. JEELS (Journal of English Education and Linguistics Studies) 6 (2): 189-213. https://doi.org/10.30762/jeels.v6i2.1233.

Ibrohim, Achmad Taufiq, Astri Septianti, and Irma Savitri Sadikin. 2019. 'STUDENTS' PERCEPTION TOWARD TEACHING ENGLISH VOCABULARY THROUGH TOTAL PHYSICAL RESPONSE (TPR) METHOD'. PROJECT (Professional Journal of English Education) 1 (2): 145-56. https://doi.org/10.22460/project.v1i2.p145-156.

Liana, -. 2018. 'PENGARUH PENGgUNAAN APLIKASI "HELLO ENGLISH" BERBASIS SMARTPHONE ANDROID TERHADAP PENINGKATAN HASIL BELAJAR SISWA PADA MATA PELAJARAN BAHASA INGGRIS DI SMP'. Other, Universitas Pendidikan Indonesia. https://doi.org/10/FIP_S_KTP_1400377_Appendix.pdf.

Maskor, Zunita Mohamad, and Harun Baharudin. 2016. 'Receptive Vocabulary Knowledge or Productive Vocabulary Knowledge in Writing Skill, Which One Important?' International Journal of Academic Research in Business and Social Sciences 6 (11): Pages 261-271. https://doi.org/10.6007/IJARBSS/v6-i11/2395.

Puspitaloka, Nina, Uswatun Hasanah, and Indah Rahmawati. 2017. 'ENGLISH VOCABULARIES ENRICHMENT THROUGH "HELLO ENGLISH" ANDROID BASED EDUCATIONAL GAME FOR YOUNG LEARNERS CLASSROOM'. In Conference Proceedings of The 2nd International Conference 2017 on Teaching English for Young Learners (TEYLIN): Indigenous Norms to the Coming Age of One Asia, 140-48.

Setiawan, Imam, and Muhammad Mujtaba Mitra Zuana. 2018. 'Teaching Vocabulary Using Modified Snakes and Ladders Game'. Alsuna: Journal of Arabic and English Language 1 (2): 87-95. https://doi.org/10.31538/alsuna.v1i2.86. 
Sudrajat, Hana Nurwahidah, and Herlina Herlina. 2015. 'MENINGKATKAN PEMAHAMAN KOSAKATA BAHASA INGGRIS MELALUI METODE PERMAINAN BINGO'. Jurnal IImiah Visi 10 (2): 114-21. https://doi.org/10.21009/JIV.1002.6.

Vesselinov, Roumen, and John Grego. 2017. 'Hello English Efficacy Study'. United States: Economics Department Queens College, City University of New York and Statistics Department University of South Carolina. 